\title{
Bacteriological Profile in Diabetic Foot Patients
}

\author{
Adriana Lam Vivanco*, Flor María Espinoza, Fabián Cuenca Mayorga, Jovanny Santos Luna, \\ Marlene Chamba Tandazo, Elida Yesica Reyes Rueda, Kerly Davila Davila
}

Technical University of Machala, Machala, Ecuador

Email: *alam@utmachala.edu.ec

How to cite this paper: Vivanco, A.L., Espinoza, F.M., Mayorga, F.C., Luna, J.S., Tandazo, M.C., Rueda, E.Y.R. and Davila, K.D. (2017) Bacteriological Profile in Diabetic Foot Patients. Journal of Diabetes Mellitus, 7, 265-274.

https://doi.org/10.4236/jdm.2017.74021

Received: August 3, 2017

Accepted: October 9, 2017

Published: October 12, 2017

Copyright $\odot 2017$ by authors and Scientific Research Publishing Inc. This work is licensed under the Creative Commons Attribution International License (CC BY 4.0).

http://creativecommons.org/licenses/by/4.0/

\begin{abstract}
One of the complications carried by diabetes clinical pictures is the so-called diabetic foot, regardless of age, genre, ethnic group, and socio-economic level; limb amputation is usually an inevitable means to an end. The present research work had the purpose to determine microorganism responsible of ulcer infection in diabetic foot on its more frequent occurrence. Diabetic foot is a public health issue for its high incidence and its high sanitary costs. The present work consisted on a descriptive-retrospective research to seventy patients who were attended in a privately-owned hospital in Machala-Ecuador. Type III (according to Wagner scale) was determined as most frequent value. Microorganisms with a higher incidence degree were found to be gram-negative bacteria Escherichia Coli 27 (69.28\%) and gram-positive bacteria Staphylococcus aereus $25(80 \%)$.
\end{abstract}

\section{Keywords}

Diabetic Foot, Bacteria, Gram-Negative, Escherichia coli, Gram-Positive, Staphylococcus aerus

\section{Introduction}

Diabetes mellitus (DM) is the name applied to the concurrence of certain processes which can be characterized with the occurrence of hyperglycemia, resulting from physio-pathological alterations, mainly induced by SIRT1 gene mutation [1]. DM is a potential problem for human health and knowledge over said etiological diversity arises as means to identify each one of the consequences involved from the disease. One of the major sources of distress regarding complications related with diabetes mellitus (DM) is the diabetic foot syndrome; the World Health Organization (WHO) defines diabetic foot as infection and destruction of deep tissues, related with neurological disorders and different degrees of peripheral vascular illness in lower limbs occurring in diabetes patients 
[2] [3] [4] [5] [6]. The depicted situation carries a high morbidity degree and a high risk of amputation. The aim of the present research was to characterize those microorganisms with a higher level of incidence in diabetic foot clinic pictures through microbiological analysis, this to enhance further prevention programmes [7]. One of the most important factor prompting to foot infection in diabetic patients are skin barrier integrity losses, as a result of decreasing in chemotactic, phagocytic, and cytotoxic capacity; as a consequence of diabetic neuropathy, losses in protective sensations may occur, which enhances the presence of lesions on the skin (mainly from traumatic origin), sensation losses, foot deformities, and joints mobility constraints, featured frequently in diabetes patients; the aforementioned usually produce changes in feet biomechanics; callus is formed and disrupts the skin barrier [2]. Microorganisms then can penetrate through those cracks formed in the skin concomitantly. Alongside with the depicted neuropathy, an ischemic factor contributing to hamper wounds and infection curative processes can be presented as an outcome [8] [9]. Symptoms may range from absence of clinic sings, evidenced by feet losing their sensitivity with ulceration risk, to unbearable neuropathic pain presence [10]. DM1 autoimmune reaction comes alongside autoantibodies production humoral counteraction. Currently, anti-glutamate decarboxylase antibodies (GAD), the most-commonly used antibodies at clinic level, are the ones used against insulin (anti-insulin IAA), decarboxylase glutamic acid (GAD) and anti-tyrosine phosphatase 2 (Langerhans' antibodies anti-isletsIA2). From a predictive point of view, the three previously-mentioned types presence in the same individual assures practically the disease development. Nonetheless, if just one of them is detected, its predictive value does not exceed $60 \%$. IA2 antibodies, when and if detected, are often associated with diabetes quick evolution [11] [12]. Patients with a diabetes mellitus diagnosis show vascular disease clinical signs, infection or neuropathy, in at least one of the lower limbs. Diabetic foot Wagner classification is the more commonly used parameter to quantify trophic lesions; in the case of diabetic foot, this classification corresponds to: Type I, evidenced with superficial ulcers without deep tissue involvement; Type II, where wounds reach tendons, joint capsule, and bones; Type III, where abscess is occurred (pus fluids accumulation), osteomyelitis (bone infection), osteoarthritis (joint wearing and tearing), and tendonitis (tendon inflammation); Type IV, evidenced with gangrene or localized gangrene incidence, usually in one part of the foot; Type V, [13] where gangrene is spread throughout the foot. Among those diabetes mellitus chronic complications, resulting from micro and macrovascular damages, diabetic foot is considered as one of the most-feared complications when patients are asked [14]. Diabetic foot aetiology includes gram-positive or gramnegative pathogens with both, aerobic or anaerobic metabolism; Staphylococcus aureus has been found to be the most important pathogen in diabetic foot infections, either as a single agent or alongside mixed infection [15] [16].

Three microorganisms can predominate in diabetic foot: Staphylococcus aureus, 
Escherichia coli, Klebbsiella; since diabetic foot infection is polymicrobial, leading to a rapid and progressive synergistic so-called wet gangrene; if not treated properly, the latter may be fatal. A fulminant infection pathognomonic sign can be described with subcutaneous emphysema development; although this might also occur in diabetes patients with infections caused by less-pathogen microorganisms such as Escherichia coli and other coliforms [17] [18] [19]. The tables (Table 1 \& Table 2) below show a compilation of toxins secreted by Grampositive and Gram-negative bacteria:

\section{Methodology}

A descriptive-retrospective study was conducted to determine the more-commonly occurred microorganisms in diabetic foot ulcers infection. The study population consisted in 70 clinical records depicting type 2 diabetes mellitus diagnosis, diabetic foot ulcer at any stage, culture application, and antibiogram. Prior au-

Table 1. Gram-positive bacteria toxins [20] [21] [22] [23].

\begin{tabular}{|c|c|}
\hline \multicolumn{2}{|c|}{ Gram-positive } \\
\hline Bacteria & Toxins \\
\hline \multirow[t]{5}{*}{ Staphylococcus aureus } & - Hemolysins \\
\hline & - Panton-Valentine leukocidin \\
\hline & - Exfoliative or epidermolytic toxins \\
\hline & - Enterotoxins \\
\hline & - Toxic-shock syndrome toxine 1 \\
\hline \multirow[t]{4}{*}{ Hemolytic Staphylococcus afa } & - Pyrogenic toxins (A, B, and C) \\
\hline & - Hemolysins \\
\hline & - Pyrogenic exotoxins ( $\mathrm{A}, \mathrm{B}$, and $\mathrm{C})$ \\
\hline & - Diphosphopyridine nucleotidase \\
\hline Staphylococcus sciuri & - Exfoliative toxins \\
\hline
\end{tabular}

Table 2. Gram-negative bacteria toxins [24]-[29].

\begin{tabular}{cl}
\hline \multicolumn{2}{c}{ Gram-negative } \\
\hline Bacteria & \multicolumn{1}{c}{ Toxins } \\
\hline Klebsiella & - Enterotoxins \\
& - Shiga toxin \\
& - Shiga toxin \\
Pantoea agglomerans & - Endotoxins \\
& - Adhesins \\
& - Enterotoxins \\
& - Shiga toxin \\
Pseudomona auruginosa & - Exotoxin A \\
& - Exotoxin S
\end{tabular}


thorization from the private clinic staff, the complete set-up of the clinical records was analysed. The following variables were studied: age (measured in years), gender, origin, lesion Wagner's classification, cultures, isolated microorganism, and antibiogram report. Analysis and data processing were performed through descriptive statistics with Origin, Statgrahics Plus Version 5.0. statistics package. The hypothesis stablished was: there is a high diabetic foot incidence with presence of both, Gram-positive bacteria Staphylococcus aureus and gram-negative bacteria Escherichia coli.

\section{Results}

\section{Socio-demographic characteristics:}

\section{Clinic characteristics}

70 patients were attended; the highest precedence index (where these patients came from) was Machala (30\%). The Pareto analysis carried out showed that the masculine gender reached a number of 42 patients $(60 \%)$, thus the highest number of cases, whereas the feminine gender reached the number of 28 (40\%) Figures 1-3 features that the age group with the highest presence was the one representing ages between 51 - 55 years, with a total number of 34 and representing the $48.57 \%$ of cases.

Table 3 shows that the highest occurrence frequency, according to Wagner classification, was diabetic foot type III (36 cases-51.43\%). A correlation between Wagner classification and microorganism type was carried out. Gramnegative bacteria showed the highest incidence of occurrence with 20 patients in type III as featured in Table 4 and Figure 4.

\section{Discussion}

Diabetic foot is one of the most prevalent complications found among those

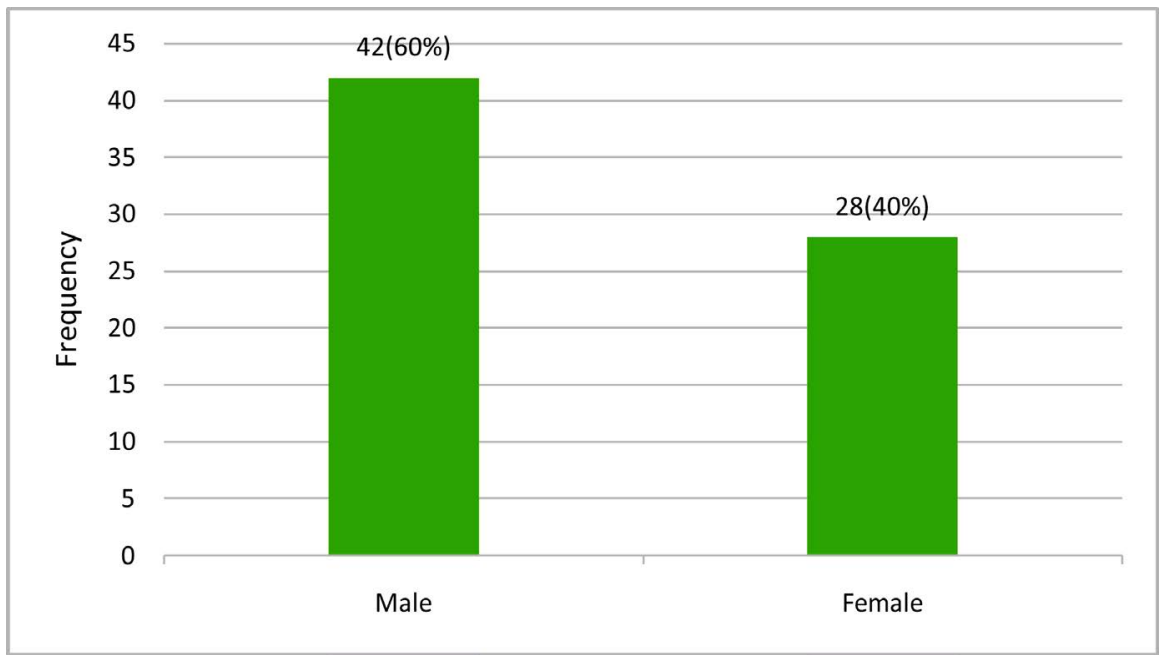

Source: Authors.

Figure 1. Percentage of diabetic foot incidence in the population studied distributed according to gender. 


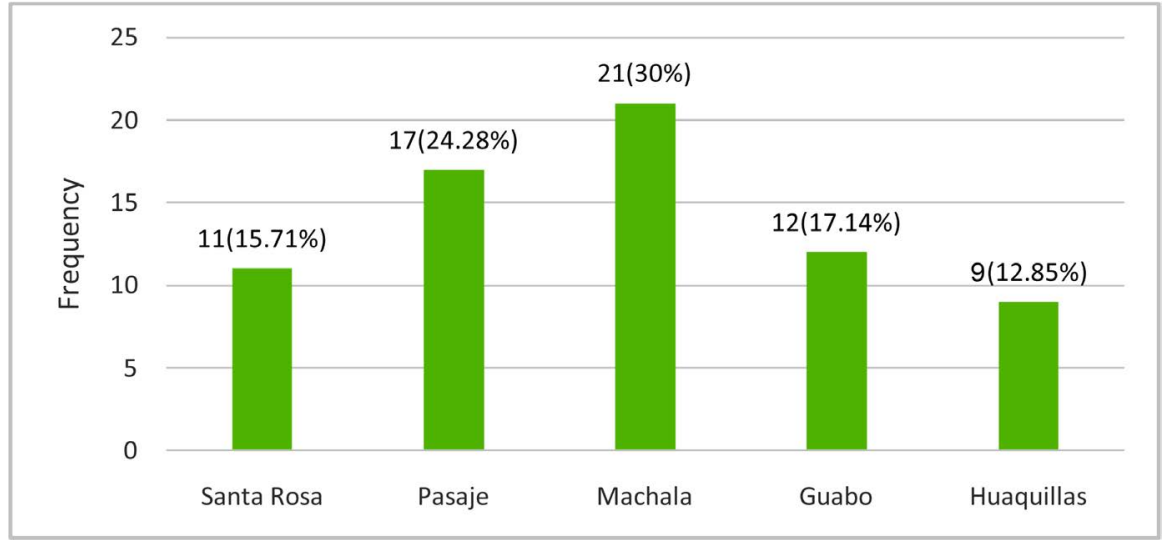

Source: Authors.

Figure 2. Percentage of patients subjected to study distributed regarding place of origin within El Oro province.

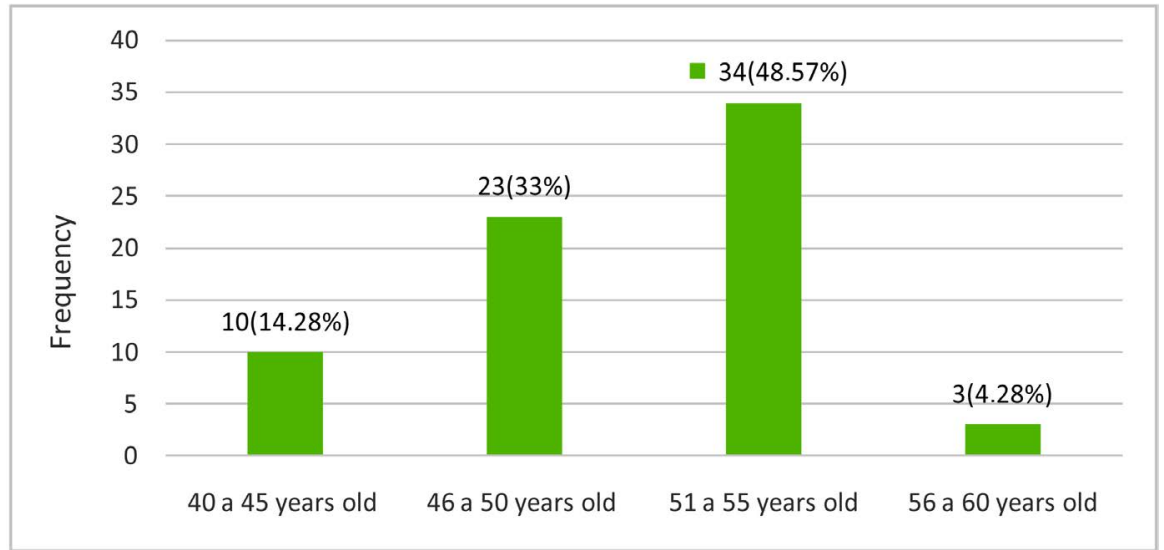

Source: Authors.

Figure 3. Distribution (in percentage) of diabetic foot incidence in the studied group accordingly to age group used.

Table 3. Pareto analysis in Wagner classification.

\begin{tabular}{cccccccc}
\hline \multicolumn{7}{c}{ Pareto Chart whit Cumulative Frequencies } \\
\hline Class Label & Rank & Count & Weight & Weighted Score & Cum. Score & Percent & Cum. Percent \\
\hline Type III & 1 & 1 & 36 & 36 & 36 & 51,43 & 51,43 \\
Type IV & 2 & 1 & 20 & 20 & 56 & 28,57 & 80 \\
Type II & 3 & 1 & 12 & 12 & 68 & 17,14 & 97,14 \\
Type V & & 1 & 2 & 2 & 70 & 2,86 & 100 \\
Total & 4 & 70 & & & & \\
\hline
\end{tabular}

Source: Authors.

provoked by diabetes clinical pictures; this is a pathology which does not make any distinction regarding gender, ethnicity, and age. In the context taken in the present investigation, data were obtained through a survey applied to a known number of patients with this anomaly; data showed that the illness was occurred 
Table 4. Diabetic foot patients' distribution accordingly to microorganism type and Wagner classification.

\begin{tabular}{rccc}
\hline & Gram-positive & Gram-negative & Total \\
\hline Type I & 0 & 0 & 0 \\
Type II & 9 & 3 & 12 \\
Type III & 16 & 20 & 36 \\
Type IV & 5 & 15 & 20 \\
Type V & 1 & 1 & 2 \\
Subtotal & 31 & 39 & \\
\hline
\end{tabular}

Source: Authors.

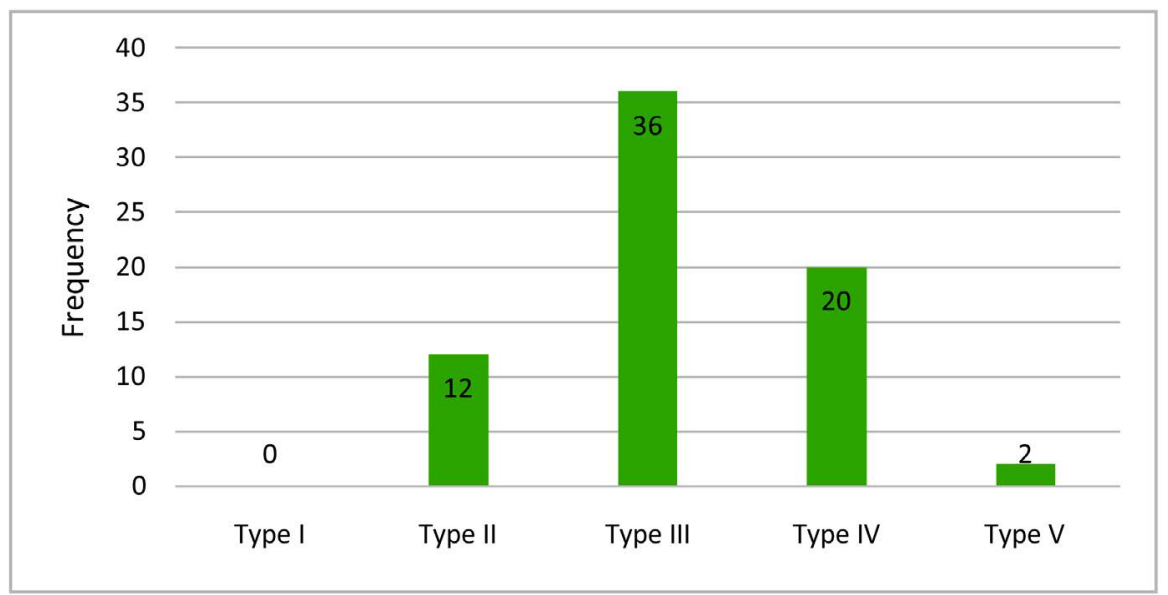

Source: Authors.

Figure 4. Wagner classification distribution (in percentage values) of patients subjected as part of the research.

predominantly in male gender (42 patients-60\%), while the figure for the female gender was 28 patients (40\%). In addition to this information, data were also obtained concerning to the age factor; the disease was found predominantly between 51 - 55 years, occurred in 34 patients (48.75\%). Figure 1 and Figure 2 show origin of patients; most patients came from the urban region of Machala, representing approximately $30 \%$.

Currently, the number of diabetic patients is increasing significantly, consequently the number of cases of diabetic foot increases concomitantly, hence, to expand the knowledge over prevention of complications due to diagnosis based on analysis of bacteria present in foot tissue injuries is necessary [30] [31] [32]. In addition, as marked out in the Pareto analysis in Table 5, it shall be noted that microorganisms found in cultures carried out for the sake of the present work pertain to Gram-negative bacteria (39 cases-55.77\%) and Gram-positive (31 cases-42\%) as illustrated in Figure 5 and in Pareto analysis in Table 6. Staphylococcus Aureus (Gram-positive bacteria found in diabetic foot clinical pictures) is sensitive to antibiotics: Aztreonan, Amikacin, Imipenen, Gentamicin, Tetracycline, Chloramphenicol and is, in the other hand, resistant to 
antibiotics such as Ampicillin, Clindamycin, Penicillin, and Ciprofloxacin. Escherichia coli (Gram-negative bacteria found in diabetic foot clinical pictures), featured in Figure 6, proved to be sensitive to antibiotics Ceftazidime Imipenem, and Phospomicia Meropenen; it was also proved to be resistant to Amikacin.

Table 5. Pareto analysis of gram-negative bacteria incidence.

\begin{tabular}{|c|c|c|c|c|c|c|c|}
\hline Class Label & Rank & Count & Weight & Weighted Score & Cum. Score & Percent & Cum. Percent \\
\hline Escherichia coli & 1 & 1 & 27 & 27 & 27 & 69.23 & 69.23 \\
\hline Klebsiella Oxytoca & 2 & 1 & 4 & 4 & 31 & 10.26 & 79.49 \\
\hline klebsiella & 3 & 1 & 4 & 4 & 35 & 10.26 & 89.74 \\
\hline Psudomonas Aerugi & 4 & 1 & 1 & 1 & 36 & 2.56 & 92.31 \\
\hline Pantroea Agglomeran & 5 & 1 & 1 & 1 & 37 & 2.56 & 94.87 \\
\hline Proteus Vulgaris & 6 & 1 & 1 & 1 & 38 & 2.56 & 97.44 \\
\hline Proteus Mirabils & 7 & 1 & 1 & 1 & 39 & 2.56 & 100.00 \\
\hline Total & & 7 & & 39 & & & \\
\hline
\end{tabular}

Source: Authors.

Table 6. Pareto analysis of gram-positive bacteria incidence.

\begin{tabular}{|c|c|c|c|c|c|c|c|}
\hline \multicolumn{8}{|c|}{ Pareto Chart whit Cumulative Frequencies } \\
\hline Class Label & Rank & Count & Weight & $\begin{array}{l}\text { Weighted } \\
\text { Score }\end{array}$ & $\begin{array}{l}\text { Cum. } \\
\text { Score }\end{array}$ & Percent & $\begin{array}{l}\text { Cum. } \\
\text { Percent }\end{array}$ \\
\hline Staphylococcus Aureus & 1 & 1 & 25 & 25 & 25 & 80.65 & 80.65 \\
\hline $\begin{array}{c}\text { Streptococcus Alfa } \\
\text { Hemolitico }\end{array}$ & 2 & 1 & 3 & 3 & 28 & 9.68 & 90.36 \\
\hline $\begin{array}{l}\text { Streptococo no } \\
\text { hemolitico }\end{array}$ & 3 & 1 & 2 & 2 & 30 & 6.45 & 96.77 \\
\hline Staphylococcus Scuri & 4 & 1 & 1 & 1 & 31 & 3.23 & 100 \\
\hline Total & & 4 & & 31 & & & \\
\hline
\end{tabular}

Source: Authors.

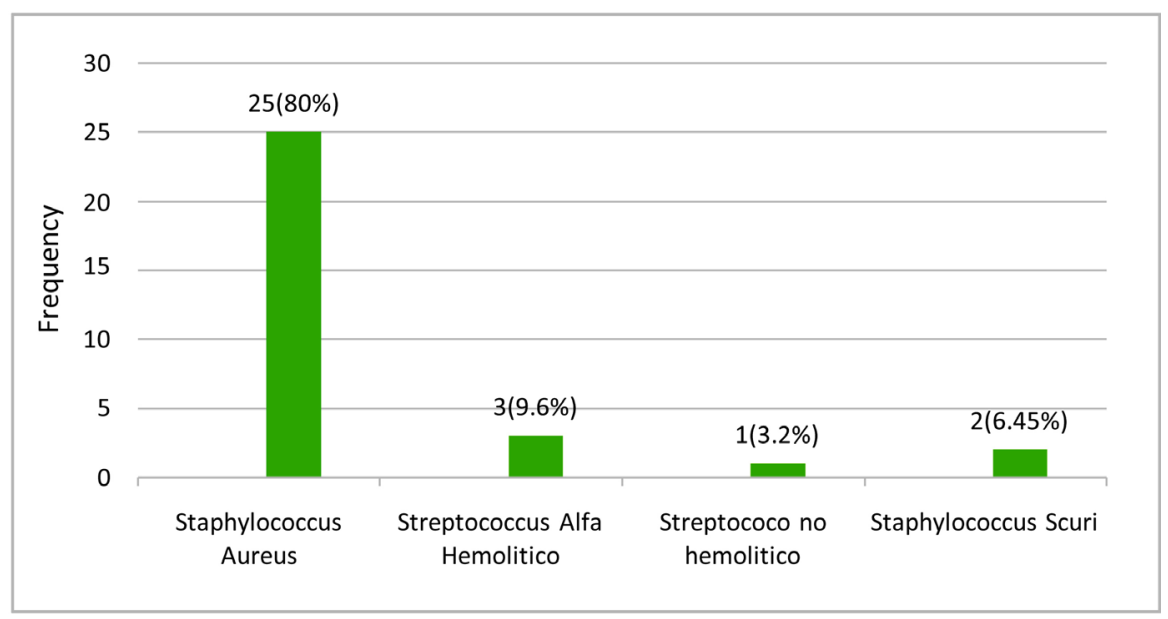

Source: Authors.

Figure 5. Gram-positive bacteria occurred in diabetic foot cases registered and distributing accordingly to its incidence (in percentage values). 


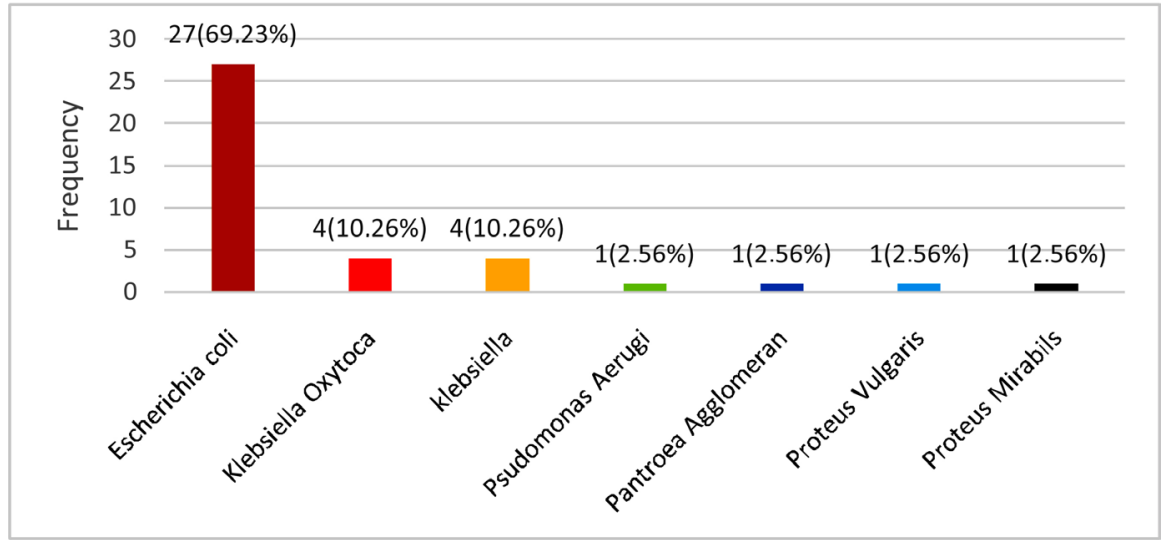

Source: Authors.

Figure 6. Gram-negative bacteria occurred in diabetic foot cases registered and distributing accordingly to its incidence (in percentage values).

\section{Conclusion}

Ulcer infection in diabetic foot clinic cases was characterized to be Type III, according to Wagner scale. Most frequent microorganisms found pertained to the Gram-negative Escherichia coli 27 (69.28\%) and gram-positive bacteria Staphylococcus aerus 25 (80\%) species, according to Pareto analysis results.

\section{Acknowledgements}

Lam, A. and Espinoza, F.M. are associate lecturers at UTMACH. Lam, A. carried out literature review previous to the present work research and carried out data compilation and experimental work; Espinoza, F.M., contributed with experimental work and interpretation. Cuenca, F. is a lecturer at UTMACH. He contributed with statistical and data interpretation review; he also contributed with text translation from its original language and subsequent redaction of the present written article. The three authors contributed equally to the present work development and review.

\section{References}

[1] Carrasco, A.J.B. (2013) Why Should We Worry about Diagnosing Monogenic Diabetes? Advances in Diabetology, 126-132.

[2] López, L.M., Jiménez, A., Lomas-Meneses, R.P., Quílez-Toboso, I. and Huguet-Moreno (2012) The Diabetic Foot. Medicine - Accredited Continuing Medical Training Program, 1032-1039.

[3] Boada, A. (2011) Skin Lesions in the Diabetic Foot. Dermatology Service, Germans Triasi Pujol University Hospital, Universitat Autónoma de Barcelona, 348-356.

[4] Herrera, A.L.G. (2015) Combined Surgical Treatment with Heberprot- $\mathrm{P}^{\circledR}$ in Neuromuscular Ulceration of the Forefoot. Angiologia e Cirurgia Vascular, 16.

[5] Hoyos, E.G., Levy, A.E., Perez, A.D., Hernandez, M.C., Zorrilla, C.M. and Pascual, A.L.C. (2012) Seminars of the Spanish Foundation of Rheumatology. Di. 119-129.

[6] Gurri, D.R. (2014) Categorization of Risk as Part of a Comprehensive Program for the Prevention of Diabetic Foot. CCM, Vol. 18, No. 3 Holguin. 
[7] Cruz-Pulido, W.L., Bladinieres-Cámara, E., Alcalá-Durán, R., Rivera-Sánchez, G., Reyes-López, M.Á. and Bocanegra-García, V. (2013) Diabetic Foot Infections: Concepts and General Consensus. área iii. Medicina y ciencias de la salud.

[8] Castellon, A., Lestania, L., Martinez, A. and Patricia, G. (2017) Gram-Positive and Gram-Negative Bacteria Isolated from Patients Diagnosed with Diabetic Foot Admitted to the Orthopedic and Traumatology Department of Hospital School Oscar Danielo Rasaless Aguello. 2011.

[9] Gamboa, M.C.R. and López, M.S. (2017) Evolution of Diabetic Foot in Grades 4 and 5 of the Wagner Classification. Revista Cubana de Angiología y Cirugía Vascular, 18,1 .

[10] Vázquez (2016) Diabetic Neuropathy and Diabetic Foot. Medicine - Accredited Continuing Medical Training Program, 971-981.

[11] Unit of the Diabetic Foot and Interdisciplinary Group of Study of Diabetic Foot of the Universidad Complutense de Madrid (2011) The "Diabetic Foot" Syndrome the Model of the Podiatric Clinic of the Complutense University of Madrid. Montesinos.

[12] Pérez, M.C. (2015) Knowledge and Habits of Care: The Effect of an Educational Intervention to Reduce the Risk of Diabetic Foot. Ciencia y Enfermería, 21, 23-36.

[13] Pupo, P. and Milena, S. (2015) Evolution of Complex Lesions in the Diabetic Foot using Heberprot. Revista Archivo Médico de Camagüey.

[14] Seijas, E.Á. (2015) Foot Risk According to Stratification in Patients with Diabetes Mellitus. La Revista Cubana de Endocrinología, 26.

[15] Hernández, M.A., Álvarez, J.A., Vaca, F.C., Cuevas, A. and Ramírez, A.J. (2011) Microbiology of the Diabetic Foot: Is Culture Taken with Swab. Medical Gazette of Mexico, 147, 117-124.

[16] Espinoza-Tavera, A., Hernandez-Garcia, G., Cantua-Ramirez, R.C., Diaz-Lopez, A., Avila-Aguilar, S., Garcia-Garcia, E.A. and Bo-canegra-garcia (2014) Prevalence and Antibiotic Resistance Profile of Microorganisms Isolated from Diabetic Foot In-Fections. UAT Science, 84-89.

[17] Cañarte-Alcívar, J., Intriago-Ganchozo, J. and Romero-Santillán, B. (2016) Prevalence of Diabetic Foot in Patients Treated at Hospital Santo Domingo de losTsáchilas. Domain of Sciences, 201-212.

[18] Martínez-Gómez, Ramírez-Almagro, C., Campillo-Soto, Á., Morales-Cuenca, G., Pagán-Ortiz, J. and Aguayo-Albasin, J.L. (2009) Diabetic Foot Infections. Prevalence of Different Microorganisms and Susceptibility to Antimicrobials. Infectious Diseases and Clinical Microbiology, 317-321.

[19] Ruiz, P.M.P., Rodríguez Leal, M.C. and de los Santos Moreno, A. (2014) Treatment Protocol for Skin Ulcers and Diabetic Foot. Medicine-Accredited Continuing Medical Training Program, 3296-3299.

[20] Rodríguez, R.G. (2015) Heberprot-P Results in Patients with Diabetic Foot Ulcers. AMC, Vol. 19, No. 4, Camagüey.

[21] Castillo, V.R. (2014) Antimicrobial Resistance of Staphylococcus aureus in Patients with Diabetic Foot. Santiago de María.

[22] Rodríguez, R.G., et al. (2015) Resultados del Heberprot-P $\mathrm{P}^{\circledast}$ en pacientes con úlceras de pie diabético. Revista Archivo Médico de Camagüey, 19.

[23] WHO. E. coli. http://www.who.int/mediacentre/factsheets/fs125/en/

[24] Pepper, I. (2012) Atlas of Immunology. http://atlas.med.uchile.cl/27.htm

[25] Sugandhi, P. and Prasanth, D.A. (2014) Microbiological Profile of Bacterial 
Pathogens from Diabetic Foot Infections in Tertiary Care Fehospitals, Salem. Diabetes \& Metabolic Syndrome, 8, 129-132.

[26] Encalada, Andres NAvarro. SlideShare. http://es.slideshare.net/andresh17/pseudomona-14600621

[27] Ibarra, A. (2015) Prevalence and Clinical Characteristics of Diabetic Patients Admitted to a General Hospital. Archivio Di Medicina Interna, 37, 57-60.

[28] Gurri, D.R. (2013) Characterization of Patients with Diabetic Foot. Cuban Revision of Military Medicine.

[29] Amarales, D. and Yamilet, E. (2014) Heberprot-P in the Treatment of Diabetic Foot Ulcers. AMC, Vol. 18, No. 3, Camagüey.

[30] Febre, N., Silva, V., Baez, A., Palza, H., Delgado, K., Aburto, I. and Silva, V. (2016) Antibacterial Behavior of Copper Particles against Microorganisms Obtained from Infected Ulcers and Their Relationship with Antimicrobial Resistance of Coumun Use. Revista Medica de Chile, 144.

[31] Salina, L.D. (2015) Treatment and Evolution of Patients with Diabetic Foot Ulcers. Rev CubanaAngiol Cir Vasc.

[32] Pereira, L. (2015) Effectiveness of an Educational Program in Patients with Diabetic Foot at Risk. Despaigne, Olga Lidia Pereira. MEDISAN, Vol. 19, No. 1. 